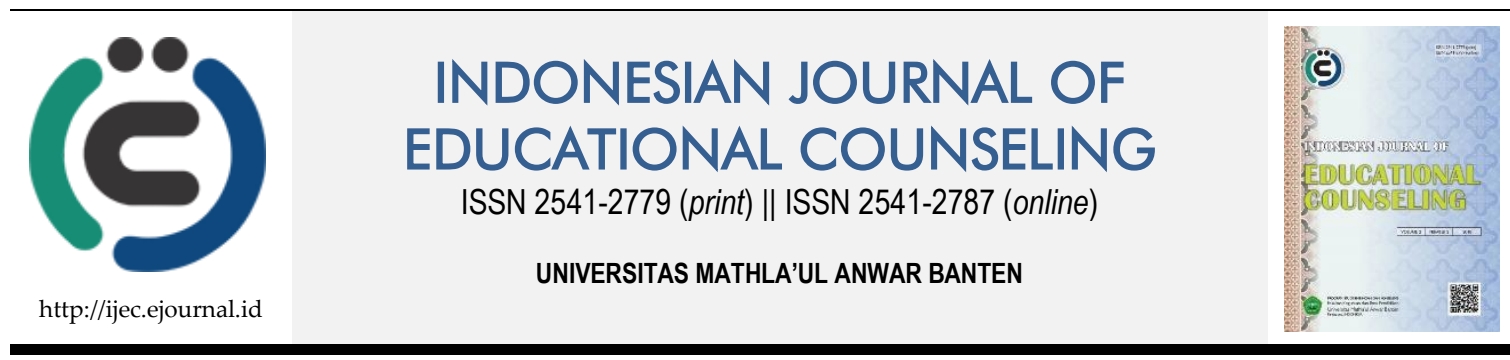

Research Based Article

\title{
Analisis Asesmen Kebutuhan Mahasiswa Terhadap Layanan Dosen Pembimbing Akademik
}

\author{
Deasy Yunika Khairun ${ }^{1}$, Ibrahim Al Hakim² \\ 1, 2 Universitas Sultan Ageng Tirtayasa
}

\begin{tabular}{|c|c|}
\hline ARTICLE INFO & ABSTRACT \\
\hline $\begin{array}{l}\text { Article History: } \\
\text { Received 12.04.2018 } \\
\text { Received in revised } \\
\text { form 18.05.2018 } \\
\text { Accepted 02.07.2018 } \\
\text { Available online } \\
\text { 21.07.2018 }\end{array}$ & $\begin{array}{l}\text { The aim of this study is to assess the needs service of Academic Advisory } \\
\text { provides guidance for students. Research also aim to found the barriers or } \\
\text { obstacles encountered academic adviser in providing academic guidance } \\
\text { services. This research use quantitative approach with questionare of Academic } \\
\text { Advisory Service, interview the students and Academic Advisory Service, and } \\
\text { documentary study. Sample in this research are students of Guidance and } \\
\text { Counseling Study Program and lecture who have the task as Academic } \\
\text { Advisory in Study Program of Guidance and Counseling. This research found } \\
\text { that the Academic Advisory has giving all indicator service based on Statuta of } \\
\text { Sultan Ageng Tirtayasa University and Standar Operational Procedur } \\
\text { Academic Advisory Service. But, there are seceral obstacles or constraints faced } \\
\text { by the Advisory Academic in the service of student guidance, such as time } \\
\text { limitation od Advisory Academic, imbalance in the ratio between the number } \\
\text { of Advisory Academid and discipline of students in following the schedule of } \\
\text { academic guidance. }\end{array}$ \\
\hline
\end{tabular}

Keywords: Academic Advisory Services, Academic Guidance. Attribution 4.0 International License, which permits unrestricted use, distribution, and reproduction in any medium, provided the original work is properly cited. (c) 2018 Deasy Yunika Khairun, Ibrahim Al Hakim.

\section{PENDAHULUAN}

Dosen Pembimbing Akademik (DPA) adalah dosen yang ditetapkan untuk melaksanakan pembimbingan kepada mahasiswa yang berfungsi sebagai sumber informasi, sebagai penampung kesulitan, sebagai petunjuk dan pemberi saran serta sebagai pemantau kegiatan mahasiswa (Susilowati, 2008). Usaha-usaha yang dilakukan oleh dosen pembimbing akademik terhadap mahasiswa bimbingan yang dilakukan secara teratur dan terarah, sehingga dapat memotivasi kegiatan belajar, yang pada gilirannya mahasiswa dapat mencapai prestasi belajar yang optimal. Pembimbingan akademik secara umum meliputi kegiatan: (1) membina dan mengarahkan mahasiswa agar dapat bersikap sebagai ilmuwan dalam rangka mengembangkan kebebasan

${ }^{1}$ Corresponding author's address: Program Studi Bimbingan dan Konseling, FKIP Universitas Sultan Ageng Tirtayasa; Jalan Ciwaru Raya No.25, Cipare, Serang, Cipare, Kec. Serang, Kota Serang, Banten 42117. Email: deasyyunikakhairun@untirta.ac.id. 
akademik sesuai dengan bidang ilmu yang ditempuhnya; (2) Menentukan jumlah beban studi yang akan diambil mahasiswa untuk semester yang sedang berjalan; (3) Memantau dan membimbing mahasiswa demi kelancaran studinya serta membantu memecahkan masalah-masalah yang dihadapi mahasiswa yang bersangkutan baik yang bersifat akademik maupun nonakademik yang diperkirakan dapat mengganggu pencapaian keberhasilan studi; dan (4) Menentukan/memutuskan boleh atau tidaknya mahasiswa yang bersangkutan menempuh ujian akhir semester.

Ada beberapa persyaratan yang harus dipenuhi dalam pelaksanaan layanan bimbingan di perguruan tinggi berdasarkan SOP FKIP Untirta, yaitu: Pertama, persyaratan umum, yaitu berkaitan dengan kelengkapan instiitusi yang penunjang upaya layanan bimbingan yang mencakup: (1) Adanya biro bimbingan dan konseling yang dilenkapi dengan bank evaluasi yaitu suatu bagian yang mengelola, mengumpulkan, menyimpan dan menggunakan alat-alat pengukuran dan evaluasi khususnya bagi kepentingan layanan bimbingan, (2) Biro Bimbingan dan Konseling harus dikoordinir oleh seorang tenaga ahli bimbingan sesuai dengan kualifikasinya dan berada di bawah lembaga perguruan tinggi yang bertanggung jawab langsung kepada rektor, (3) Biaya dan fasilitas yang diperlukan untuk menjalankan program layanan bimbingan haruslah menjadi bagian integral dari keseluruhan pembelajaran perguruan tinggi yang bersangkutan, (4) Isi program bimbingan haruslah disesuaikan dengan ciri khas masa perkembangan yang dialami oleh mahasiswa pada umumnya, (5) Layanan-layanan bimbingan haruslah menjangkau ke seluruh mahasiswa dan dapat dirasakan manfaatnya oleh semua mahasiswa di perguruan tinggi yang bersangkutan.

Kedua, berkaitan dengan ketenagaan, yang meliputi: (1) Adanya seorang konselor umum (general counselor) yaitu seorang yang menguasai teori, pendekatan, metode dan teknik layanan Bimbingan dan Konseling. Idealnya ia adalah seorang spesialis dalam layanan bimbingan dan bukan seorang tenaga pengajar yang ahli dalam bidanh]g bimbingan melainkan ahli dalam bidang praktek layanan bimbingan serta bisa memimpin atau menjadi koordinator biro bimbingan dan konseling, (2) Adanya konselor yang merangkap seagai dosen dan minmal satu orang pada setiap fakultas. Dosen ini diharapkan selain bisa melaksanakan perkuliahan Bimbingan dan Konseling, juga bisa melakukan praktek Bimbingan dan Konseling, (3) Adanya tenaga ahli dalam menganalisis hasil testing psikologis karena dalam layanan Bimbingan dan Konseling tidak akan lepas dari evaluasi yang bersifat psikologis, (4) Adanya dosen penasehat atau dosen wali (nama ini disesuaikan dengan ciri masing-masing perguruan tinggi) yang ikut berperan dan mendampingi dosen Bimbingan dan Konseling dan bahkan (dalam kondisi tertentu bisa melayani konsultasi individual) karena di sebuah perguruan tinggi tidak akan terlepas dari peran dosen penasehat akademik, (5) Adanya peran aktif dosen ahli mata kuliah yang menyediakan peluang untuk mengadakan konsultasi kepada mahasiswa berkisar masalah studi, cara belajar yang mandiri, cara menelusuri informasi, cara membuat sinopsis dan proposal penelitiaan/skripsi dan sebagainya. Namun perlu disadari bahwa tugas dosen penasehat tidak boleh "merampas" wewenang dari petugas layanan bimbingan dan konseling, (6) Adanya petugas tata usaha layanan bimbingan. Tenaga ini adalah seorang yang telah dididik dan dilatih dalam layanan Bimbingan dan Konseling sehingga ia memahami prinsip-prinsip bimbingan, administrasi dan organisasi bimbingan, prosedur pencatatan, penyimpanan, pengolahan dan pemanfaatan data bagi keperluan Bimbingan dan Konseling. Tenaga ini dapat pula merangkap sebagai tenaga resepsionis bimbingan dengan tambahan persyaratan tentang ciri-ciri penampilan dan pribadi serta hubungan sosial yang mendukung. 
Ketiga, berkaitan dengan persyaratan khusus dosen penasehat, Dosen penasehat mempunyai andil yang besar untuk kelancaran pelaksanaan bimbingan, serta fungsi penyaluran dan penyesuaian dalam layanan bimbingan, sehingga dosen penasehat harus memiliki kriteria sebagai berikut: (1) Adanya kesediaan dosen penasehat untuk mengadakan hubungan yang erat dengan mahasiswa asuhannya yang tidak hanya terbatas pada pertermuan di kelas saja, (2) Adanya kesediaan dosen penasehat untuk memberikan perhatian yang cukup bagi setiap diri mahasiswa asuhannya, (3) Adanya kesediaan dosen penasehat untuk menyediakan waktu guna memberikan kesempatan mengadakan pertemuan yang bersifat psibadi dengan mahasiswanya, (4) Adanya kesediaan dosen penasehat untuk melakukan berbagai kegiatan pendidikan dalam rangka membantu perkembangan pribadi mahasiswa secara optimal, (5) Adanya jarak ikatan psikologis yang tidak terlalu jauh dan tidak pula terlalu dekat terhadap mahasiswa yang menjadi asuhannya, (6) Adanya kesediaan dosen penasehat untuk menjaga rahasia mahasiswa bimbingannya, sehingga dapat mempertinggi marwah dan integritas dosen penasehat. Dengan demikian, layanan bimbigan konseling di perguruan tinggi pada hakikatnya masih manjadi lanjutan proses layanan bimbingan jenjang sekolah sebelumnya dengan memperhatikan perkembangan, kebutuan, ciri khas, tuntutan kehidupan kampus, memanfaatkan potensi, mengembangkan kepribadian, sehingga tercapai pribadi yang totalitas dan optimal.

Secara periodik mahasiswa digolongkan pada umur lebih kurang 18-19 tahun sampai dengan umur 22-23 tahun. Mahasiswa pada rentang usia tersebut telah memasuki masa remaja akhir dan memasuki masa dewasa awal. Dalam perspektif psikologis, rentang usia ini mempunyai ciri: (1) reproductive age atau usia reproduktif, (2) setting down age atau usia memantapkan letak kedudukan, (3) problem age atau usia banyak masalah dan, (4) emotional tension atau usia tegang dalam emosi (Mappiare, 1983). Periode tersebut merupakan periode dan fase yang membutuhkan layanan bimbingan.

Mahasiswa mendambakan menjadi sosok yang idealis, penuh tanggung jawab, percaya diri, aktualisasi diri, superiority dan sebagainya.Namun pada sisi lain, mahasiswa adalah sosok individu yang "masih lemah", sulit menetukan pilihan, kepribadian yang ambigu, ketergantungan, ragu-ragu dan inferiority. Kondisi-kondisi seperti ini mengindikasikan bahwa layanan bimbingan yang dilakukan oleh DPA seharusnya diaplikasikan secara serius, perancangan program-program secara sistematis, memperhatikan kebutuhan baik fisik maupun psikis, mengembangkan berbagai potensi yang dimiliki, memperhatikan kecerdasan jamak (multiple intelligences) yang dimiliki mahasiswa dan memaksimalkan usaha layanan bimbingan, sehingga mahasiswa berkembang optimal sesuai dengan potensi yang dimilikinya.

\section{METODE}

\section{Pendekatan Penelitian}

Penelitian merupakan penelitian deskriptif dengan metode kuantitatif. Penelitian kuantitatif merupakan penelitian yang mendeskripsikan suatu gejala, peristiwa, kejadian yang terjadi saat sekarang. Penelitian deskriptif memusatkan perhatian kepada masalahmasalah aktual sebagaimana adanya saat penelitian berlangsung.

\section{Populasi dan Sampel Penelitian}

Populasi penelitian adalah mahasiswa seluruh angkatan Program Studi Bimbingan dan Konseling yang berjumlah 185 orang. Penarikan sampel penelitian menggunakan 
teknik sampling jenuh, artinya seluruh populasi merupakan atau menjadi sampel di dalam penelitian.

\section{Metode Pengumpulan Data}

Metode pengumpulan data adalah teknik atau cara-cara yang dapat digunakan oleh peneliti untuk mengumpulkan data (Riduwan, 2012). Berikut metode-metode yang digunakan dalam penelitian:

Angket

Angket/kuesioner adalah teknik pengumpulan data yang dilakukan dengan cara memberikan seperangkat pertanyaan atau pernyataan kepada orang lain yang dijadikan responden untuk dijawabnya (Sugiyono, 2010). Teknik angket digunakan untuk mengumpulkan data terkait data layanan Dosen Pembimbing Akademik pada mahasiswa Program Studi Bimbingan dan Konseling Fakultas Keguruan dan Ilmu Pendidikan Universitas Sultan Ageng Tirtayasa (Untirta) tahun akademik 2017-2018.

\section{Wawancara}

Wawancara adalah dialog yang dilakukan oleh pewawancara (interview) untuk memperoleh informasi dari informan (Sugiyono, 2011). Wawancara yang dilakukan dalam penelitian ini adalah wawancara dengan panduan yang telah disusun kepada mahasiswa Program Studi Bimbingan dan Konseling.

\section{Dokumentasi}

Dokumentasi merupakan suatu teknik pengumpulan data yang diperoleh melalui peninggalan tertulis, seperti arsip-arsip dan juga buku-buku tentang pendapat, teori, dalil, atau hukum-hukum, dan lain-lain yang berhubungan dengan masalah penelitian (Margono, 2017). Sumber dokumen dalam penelitian didapat dari Berita Acara Bimbingan Akademik dan Buku Bimbingan Akademik Mahasiswa.

\section{Analisis Data}

Penelitian ini menggunakan teknik analisa deskriptif yaitu analisa yang ditujukan untuk memaparkan objek tertentu. Analisis data merupakan proses mencari dan menyusun secara sistematis data yang diperoleh dari hasil wawancara dan catatan lapangan, sehingga dapat mudah dipahami dan temuannya dapat di informasikan kepada orang lain (Maleong, 2006).

Dantes (2012) mengungkapkan analisis data terdiri dari tiga alur kegiatan secara interaktif dan berlangsung secara terus menerus sampai tuntas, yaitu: 1) Reduksi data diartikan sebagai merangkum, memilih hal-hal yang pokok dan memfokuskan pada halhal yang penting yang muncul dari catatan lapangan. Reduksi data yang dilakukan adalah memilih data-data yang penting sesuai dengan fokus yang terjadi dilapangan; 2) Penyajian data adalah sebagai sekumpulan informasi yang tersusun dalam pola hubungan, sehingga mudah untuk dipahami apa yang terjaadi. Penyajian datadilakukan berdasarkan hasil informasi yang diperoleh dari lapangan yang tersusun secara berurutan, sehingga menjadi pola hubungan agar mudah dipahami; 3) Menarik kesimpulan. Tahapan terakhir dalam analisis data yang diilakukan adalah menyimpulkan semua informasi atau data yang diperoleh dari hasil penelitian. 


\section{HASIL DAN PEMBAHASAN}

\section{Asesmen Kebutuhan Mahasiswa Terhadap Layanan DPA}

Berikut disajikan profil asesmen kebutuhan mahasiswa terhadap layanan Dosen Pembimbing Akademik. Profil didapatkan dari hasil penyebaran angket/kuesioner pada 185 mahasiswa Program Studi Bimbingan dan Konseling:

Gambar 1. Bagan Asesmen Kebutuhan Mahasiswa Terhadap Layanan DPA

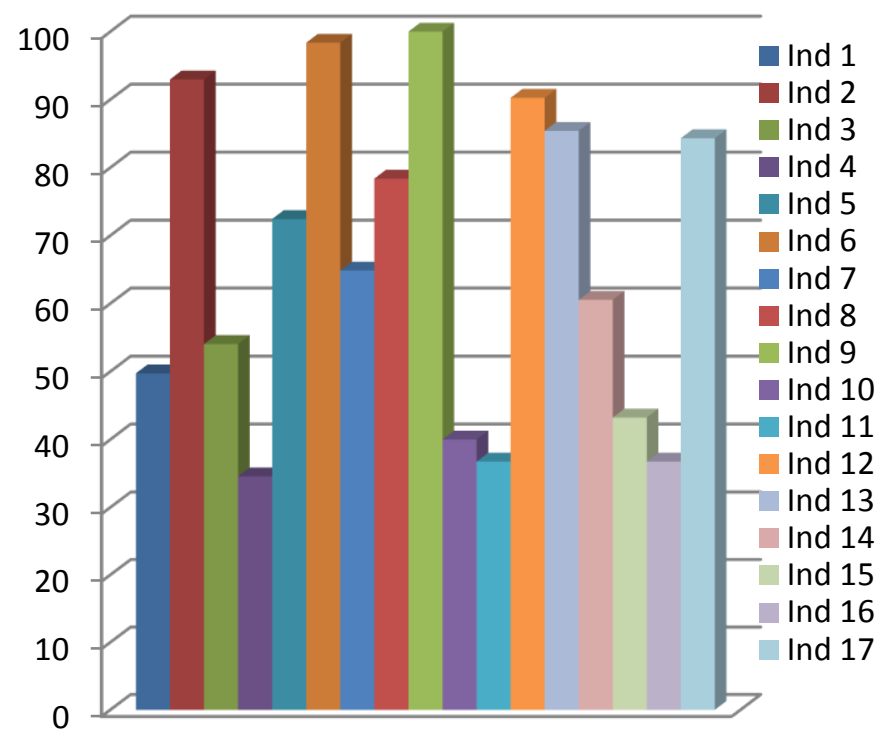

Berdasarkan bagan pada Gambar 1, secara umum kebutuhan mahasiswa tentang layanan yang diberikan oleh Dosen Pembimbing Akademik adalah sebagai berikut.

1) Indikator 2 sebanyak 92,97\% mahasiswa Program Studi Bimbingan dan Konseling (Prodi BK) menginginkan adanya komunikasi yang efektif dengan Dosen Pembimbing Akademik via telepon/email.

2) Indikator 3 sebanyak 54,05\% mahasiswa Prodi BK menginginkan DPA dapat menguasai informasi secara komprehensif tentang pedoman akademik di Untirta.

3) Indikator 5 sebanyak 72,43\% mahasiswa Prodi BK menginginkan DPA yang mengetahui informasi mengenai prospek karier.

4) Indikator 6 sebanyak 98,38\% mahasiswa Prodi BK menginginkan DPA yang mengetahui informasi pendidikan lanjut yang dapat mahasiswa tempuh pada masa yang akan dating.

5) Indikator 7 sebanyak 64,86\% mahasiswa Prodi BK menginginkan DPA yang menguasai layanan di dalam kampus Untirta. Layanan-layanan yang terdapat di dalam kampus Untirta meliputi layanan bimbingan dan konseling, layanan minat dan bakat, layanan pembinaan soft skills, layanan beasiswa, dan layanan kesehatan.

6) Indikator 8 sebanyak 78,38\% mahasiswa Prodi BK menginginkan DPA yang dapat menggunakan sarana SIAKAD untuk memantau kemajuan prestasi akademik mahasiswa. Selama ini Dosen Pembimbing Akademik masih menggunakan cara yang manual, yaitu menginstruksikan mahasiswa untuk mengumpulkan KRS atau KHS hardcopy kepada dosen. Hal tersebut sebetulnya tidak perlu dilakukan karena Dosen 
Pembimbing Akademik dapat secara otomatis mengakses KRS dan KHS mahasiswa menggunakan SIAKAD.

7) Indikator 9 sebanyak 100\% mahasiswa Prodi BK menginginkan DPA yang menggunakan sarana SIAKAD untuk memvalidasi KRS mahasiswa. Hal ini sudah dilakukan oleh seluruh akun Dosen Pembimbing Akademik, akan tetapi ada sebagian dosen yang meminta bantuan staf jurusan untuk memvalidasi KRS.

8) Indikator 12 90,27\% mahasiswa Prodi BK menginginkan DPA menjelaskan seluruh persyaratan (requirement) perkuliahan di program studi saat saya menjadi mahasiswa baru.

9) Indikator 13 sebanyak $85,41 \%$ mahasiswa Prodi BK menginginkan DPA mendorong mahasiswa untuk aktif dalam kegiatan kampus atau kesempatan belajar di luar kelas lain.

10) Indikator 14 sebesar 60,54\% mahasiswa Prodi BK menginginkan DPA yang membantu mahasiswa mengatasi kesulitan belajar.

11) Indikator 17 sebesar $84,32 \%$ mahasiswa Prodi BK menginginkan DPA yang membantu mahasiswa pada semester-semester awal menghadapi masa transisi dari SMA ke Universitas.

Berdasarkan data di atas, terdapat enam indikator yang tinggi. Pada indikator pertama, mahasiswa menginginkan Dosen Pembimbing Akademik dapat ditemui dengan mudah. Sesuai dengan wawancara yang telah dilaksanakan kepada Dosen Pembimbing Akademik, kendala yang sering dirasakan adalah banyaknya kegiatan yang harus dijalani sehingga waktu menjadi kendala. Dalam kegiatan sehari-hari, seorang dosen dihadapkan pada terbatasnya waktu yang ada. Terdapat kegiatan yang harus selalu dilakukan sesuai dengan Tri Darma Perguruan Tinggi, yaitu Pendidikan dan Pengajaran, Penelitian, serta Pengabdian Pada Masyarakat.Dosen Pembimbing Akademik memiliki waktu yang kurang untuk melaksanakan bimbingan akademik dengan mahasiswa.

Pada indikator 4, mahasiswa Program Studi Bimbingan dan Konseling menginginkan Dosen Pembimbing Akademik menguasai kurikulum program studi. Dosen Pembimbing Akademik di Program Studi Bimbingan dan Konseling berjumlah delapan orang. Tiga orang dosen memiliki latar keilmuan Bimbingan dan Konseling, sedangkan lima orang dosen berasal dari luar latar keilmuan Bimbingan dan Konseling. Berdasarkan hal tersebut, terdapat kesulitan pada Dosen Pembimbing Akademik yang memiliki latar keilmuan di luar Bimbingan dan Konseling untuk dapat menjelaskan kurikulum di Program Studi Bimbingan dan Konseling pada mahasiswa yang dibimbingnya.

Pada indikator 10, mahasiswa Program Studi Bimbingan dan Konseling menginginkan Dosen Pembimbing Akademik dapat melaksanakan proses bimbingan sesuai dengan frekuensi yang telah ditentukan. Sesuai dengan Statuta dan SOP Fakultas Keguruan dan Ilmu Pendidikan (FKIP) Untirta, kegiatan pembimbingan dilakukan pada:

Awal semester, yakni pada saat menjelang dimulainya perkuliahan. Jadwal pembimbing ditentukan dalam kalender akademik. Kegiatan pembimbingan pada awal semester berupa penentuan beban studi yang akan diambil mahasiswa. Pada saat memutuskan jumlah beban studi, Pembimbing Akademik wajib memberi penjelasan secukupnya atas keputusan tersebut agar mahasiswa dapat menyadari dan menerima putusan tersebut dengan penuh pengertian. 
Sepanjang semester, yaitu sepanjang berlangsungnya perkuliahan pada semester yang bersangkutan. Jadwal kegiatan ditentukan bersama antara Pembimbing Akademik dan mahasiswa yang bersangkutan. Apabila terdapat mahasiswa yang tidak menemui Pembimbing Akademik untuk mengemukakan masalahnya, Pembimbing Akademik wajib mengambil sikap untuk memanggil mahasiswa yang diperkirakan mempunyai masalah dengan tujuan menggali informasi yang diperlukan untuk kepentingan pembimbingan.

Akhir semester, yaitu pada saat menjelang diselenggarakan ujian akhir semester. Kegiatan pembimbingan pada akhir semester berupa pemberian informasi kepada mahasiswa yang bersangkutan menempuh ujian semester.

Pada indikator 11, mahasiswa masih enggan menjelaskan harapan dirinya pada Dosen Pembimbing Akademik. Mahasiswa merasa sungkan ketika harus bercerita kepada dosen.Mahasiswa yang mempunyai kesulitan baik akademik maupun nonakademik sering merasa sungkan untuk berkonsultasi dengan dosen.Mahasiswa malu apabila masalah pribadinya diketahui oleh dosen dan takut jika hanya masalah sederhana tetapi tidak mampu memecahkan, sehingga mahasiswa lebih baik memendam sendiri masalah yang dihadapinya atau menceritakan pada temannya. Hal tersebut akan berimplikasi pada respon dosen kepada mahasiswa. Kurang terbukanya mahasiswa kepada pembimbing akademik membuat kesulitan bagi dosen dalam memberikan saran dan petunjuk yang tepat.

Pada indikator 15, mahasiswa Program Studi Bimbingan dan Konseling menginginkan Dosen Pembimbing Akademik (DPA) dapat mencari informasi jawaban kepada pihak yang berkompeten apabila tidak mengetahui jawaban yang mahasiswa ajukan. Secara ideal, Dosen Pembimbing Akademik selalu mengikuti perkembangan situasi dan kondisi yang ada, khususnya yang terjadi di dunia pendidikan (Susilowati, 2008). Hal ini dikarenakan fungsinya/peranannya sebagai sumber informasi.Mahasiswa yang memerlukan informasi dan dapat memperolehnya dari Dosen Pembimbing Akademik. Informasi yang sering diminta oleh mahasiswa antara lain tentang perkembangan dunia pendidikan baik kurikulum, buku referensi terbaru maupun informasi tentang beasiswa.

Informasi tentang peluang usaha juga sering ditanyakan oleh mahasiswa. Hal ini untuk mengantisipasi dan mempersiapkan diri untuk terjun di dunia kerja.Dengan diketahuinya peluang kerja, maka mahasiswa dapat membuat strategi yang terbaik dalam bersaing di dunia kerja nantinya.

Pada indikator 16, DPA memiliki kepedulian yang masih harus ditingkatkan kepada mahasiswa secara pribadi. DPA memiliki fungsi membantu mahasiswa dalam menyusun rencana studi, membantu mahasiswa dalam mempertimbangkan mata kuliah yang akan diambil sesuai dengan beban sks yang dapat diambil dan memvalidasi, dan memonitor dan mengevaluasi perkembangan studi mahasiswa (Lusikooy, 1983). Dosen Pembimbing Akademik memiliki wewenang untuk memberi nasihat dan peringatan bila mahasiswa melakukan pelanggaran, membantu mengatasi masalah (masalah studi atau pribadi) yang menghambat kelancaran studi dan mengatasi kesukaran mahasiswa dalam studi, meneruskan permasalahan mahasiswa yang bukan wewenangnya kepada yang berwenang untukmenangani masalah tersebut, serta memberi bimbingan bagi mahasiswa dalam memecahkan masalah studi. Kemudian, DPA juga memiliki kewajiban untuk menguasai kurikulum program studi yang diikuti oleh mahasiswa, mengenal situasi akademik jurusan/bagian yang terkait, mengetahui berbagai program kemahasiswaan, 
menetapkan dan mengumumkan jadwal pembimbingan, melayani mahasiswa bimbingan dengan sebaik-baiknya, melapor kepada ketua atau sekretaris jurusan/bagian apabila meninggalkan tugas, dan memiliki catatan hasil pemantauan mahasiswa bimbingan (Nurihsan, 2011).

\section{SIMPULAN}

Layanan yang harus diberikan oleh Dosen Pembimbing Akademik kepada Mahasiswa meliputi 17 indikator: yaitu (1) DPA mudah ditemui, (2) Mahasiswa dapat berkomunikasi dengan DPA via telepon/email, (3) DPA menguasai informasi pedoman akademik, (4) DPA menguasai kurikulum program studi, (5) Pembimbing Akademik mengetahui informasi mengenai prospek karier, (6) Pembimbing Akademik mengetahui informasi pendidikan lanjut yang dapat mahasiswa tempuh pada masa yang akan dating, (7) DPA menguasai layanan di dalam kampus, (8) DPA mampu menggunakan sarana SIAKAD untuk memantau kemajuan prestasi akademik mahasiswa, (9) DPA menggunakan sarana SIAKAD untuk memvalidasi KRS mahasiswa, (10) Mahasiswa melaksanakan bimbingan akademik dengan DPA sebanyak minimal 4 kali dalam satu semester, (11) DPA yang dapat menjelaskan harapannya kepada mahasiswa, dan mau mendengarkan harapan mahasiswa, (12) DPA menjelaskan seluruh persyaratan (requirement) perkuliahan di Prodi saat pada mahasiswa baru, (13) DPA mendorong mahasiswa untuk aktif dalam kegiatan kampus atau kesempatan belajar di luar kelas lain, (14) DPA membantu mahasiswa mengatasi kesulitan belajar, (15) DPA yang menanyakan ke teman sejawat atau kepada pihak yang berkompeten apabila tidak mengetahui jawaban yang mahasiswa ajukan, (16) DPA peduli kepada mahasiswa secara pribadi, dan (17) Pembimbing Akademik membantu saya pada semester-semester awal menghadapi masa transisi dari SMA ke perguruan tinggi.

\section{REFERENSI}

Arikunto, S. (2012). Prosedur penelitian suatu pendekatan praktik. Jakarta: Rineka Cipta.

Dantes, N. (2012). Metode penelitian. Yogyakarta: Penerbit Andi.

Lusikooy. (1983). Bimbingan dan penyuluhan di perguruan tinggi. Jakarta: Gunung Agung.

Maleong, L. J. (2006). Metodologi penelitian kualitatif. Bandung: Remaja Rosdakarya.

Margono. (2012). Metodologi penelitian pendidikan. Bandung: Rineka Cipta.

Nurihsan, A. J. (2011). Bimbingan dan konseling dalam berbagai latar kehidupan. Bandung: Refika Aditama.

Riduwan. (2012). Belajar mudah penelitian untuk guru-karyawan dan peneliti pemula. Bandung: Alfabeta.

Sugiyono. (2010). Metode penelitian pendidikan pendekatan kuantitatif, kualitatif, dan RED. Bandung: Alfabeta.

Susilowati, T. (2008). Peran dosen pembimbing akademik terhadap prestasi belajar mahasiswa. Jurnal MIIPS. 8(2).57-65. 